\title{
A Case of Pediatric Mumps Parotitis Preceded by Acute Hearing Loss and Vertigo
}

\author{
Sang-Hyun Park, Bong-Jik Kim, and Jae-Yun Jung \\ Department of Otorhinolaryngology-Head \& Neck Surgery, Dankook University College of Medicine, Cheonan, Korea
}

\author{
소아에서 급성 난청 및 현훈이 선행한 볼거리 이하선염 1예 \\ 박상현 · 김봉직 · 정재윤 \\ 단국대학교 의과대학 이비인후-두경부외과학교실
}

\author{
Received June 17, 2014 \\ Revised September 3, 2014 \\ Accepted September 17, 2014 \\ Address for correspondence \\ Jae-Yun Jung, MD \\ Department of Otorhinolaryngology- \\ Head \& Neck Surgery, \\ Dankook University \\ College of Medicine, \\ 201 Manghyang-ro, \\ Dongnam-gu, Cheonan 330-715, \\ Korea \\ Tel $+82-41-550-3973$ \\ Fax +82-41-556-1090 \\ E-mail jjkingy2k@gmail.com
}

\begin{abstract}
We report a case of Mumps deafness with acute vestibular symptoms in a 13-year-old boy, who developed both parotid swelling preceded by acute right hearing loss and vertigo with spontaneous nystagmus. He was diagnosed as Mumps when the antibody of Mumps virus was detected in the serum. To our knowledge, this is the first case of Mumps infection, where parotitis was preceded by hearing loss and vertigo. This study indicates that the first symptom of Mumps virus infection could be hearing loss or vertigo. Korean J Otorhinolaryngol-Head Neck Surg 2015;58(3):214-6
\end{abstract}

Key Words Hearing loss · Mumps virus · Vertigo.

\section{서 론}

Mumps 바이러스는 paramyxovirus에 속하는 바이러스 로 주로 일측 혹은 양측의 이하선을 침범하여 이하선염을 일 으키며 그 외 다기관에 침범하여 뇌수막염, 고환염, 췌장염 등을 일으킬 수 있다. 이비인후과 영역에서는 감각신경성 난청, 전정신경염 등을 일으킬 수 있다. 국내에서는 1995년에 Lee 드이이 바이러스성 이하선염에 동반된 급성난청을 보고하였 고, 2008년에 Kwon 등리 이 바이러스성 이하선염에 동반된 전 정신경염을 보고하였다. Mumps 바이러스 감염에 있어서 중 요한 임상 양상은 이하선의 종창이다. 종창 발생 후에 난청 이 발생하는 경우들이 보고되고 있으며, ${ }^{3,4}$ 감각신경성 난청 과 함께 전정신경의 기능손상을 동시에 보인 경우도 보고되 었다. ${ }^{5)}$ 하지만 이는 이하선염 발생 이후에 난청과 전정기능 이상의 소견을 보였던 경우로 난청이 선행된 경우를 보고한 바는 없다. 이에 저자들은 감각신경성 난청과 급성 전정기능
저하 후에 이하선염이 발생하여 Mumps 바이러스 감염으로 확진된 1예를 문헌고찰과 함께 보고하고자 한다.

\section{증 례}

13세 남아가 내원 5일 전 발생한 경부의 열감으로 개인 소 아청소년과의원에서 경구 항생제를 처방 받아 복용하던 중 내원 4일 전부터 우측 청력소실 및 현훈이 발생하였고, 내원 1 일 전 양측 경부의 종창이 발생하여 이에 대한 진료 기록 및 소견서를 지참하여 본원 이비인후과 외래에 내원하였다. 내원 당시 우측 청력감소, 이명, 이충만감과 주위가 도는 양 상의 어지럼을 호소하고 있었다. 신체검사에서 양측 이하선 의 종창을 보였고 양측 고막은 정상 소견을 보였으며 전신 발열은 보이지 않았으나, 대칭적인 경부의 통증, 압통, 열감이 있었다. 또한 고환의 통증, 압통, 열감은 관찰되지 않았다. 환 아는 Measles, Mumps, Rubella 예방접종을 받았고, 신경학적 
검사에서 특이 소견은 발견되지 않았다.

환아는 입원 후 청력에 관하여 순음청력검사, 어음판별도 검사, 변조이음향방사검사, 뇌간유발검사를 시행하였고 현훈 에 대해 비디오안진검사, 양온교대 온도안진검사, 전정 유발 근전위검사, 주관적 시수직, 시수평 검사를 시행하였다. 검사

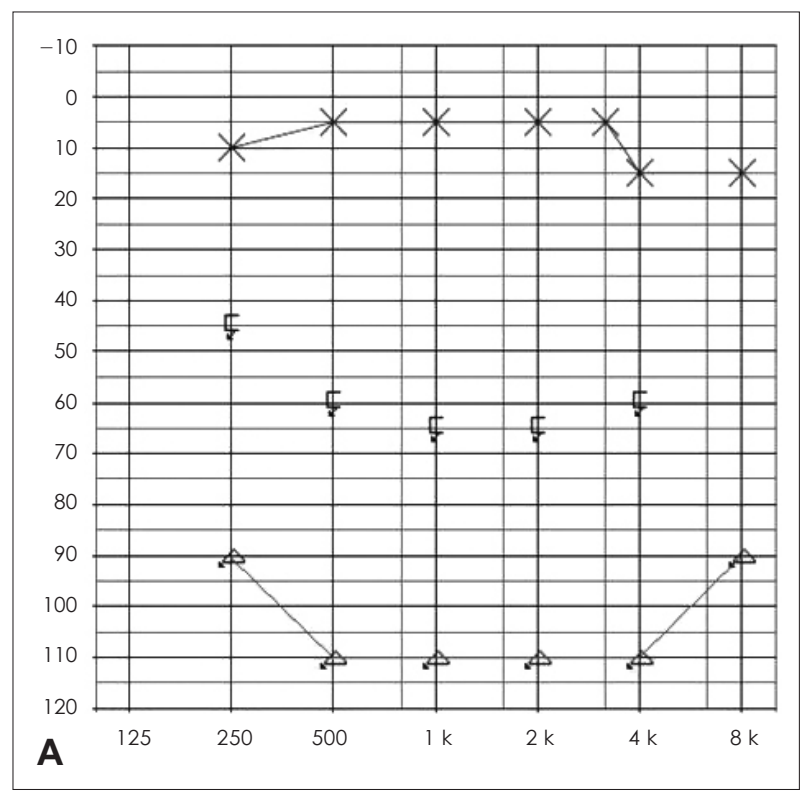

\begin{tabular}{cccc|}
\hline & & & \\
\hline$R$ & SRT $(\mathrm{dB})$ & SDS $(\%)$ & $M L(\mathrm{~dB})$ \\
$\mathrm{L}$ & $\mathrm{NR}$ & & 55 \\
\hline
\end{tabular}

\section{B}

Fig. 1. Tests obtained 5 days after the onset of vertigo and right hearing loss. Right side is complete deaf. Pure tone audiogram (A). Speech audiogram (B). SRT: speech reception threahold, SDS: speech discrimination sciores, ML: masking level.
결과 순음청력검사에서 우측 전농 소견을 보였다(Fig. 1). 변 조이음향방사검사에도 우측의 반응이 없었으며, 뇌간유발검사 에서도 우측의 경우 $90 \mathrm{~dB} \mathrm{nHL}$ 의 최고 자극에도 유발 반응 을 관찰할 수 없었다.

비디오안진검사상 전 시야에서 좌측으로 향하는 수평 회 전성 자발안진 소견이 보였고 느린 성분 안구운동속도는 평 균 $25 \% \mathrm{sec}$ 였으며 주시 고정에 의해 안진의 억제가 충분히 이 루어졌다(Fig. 2A). $17^{\circ} \mathrm{C}$ 의 단온 온도안진검사에서는 우측에 서 보정 수치로 $2 \% \sec$ 의 완서상 속도를 보였으며 좌측에서는 $30 \% \mathrm{sec}$ 의 완서상 속도를 보여 우측 전정기능 소실 소견을 보 였다(Fig. 2B and C). 전정 유발근전위검사에서는 우측귀에 $500 \mathrm{~Hz}$ 의 tone burst 자극음을 $100 \mathrm{~dB} \mathrm{nHL}$ 강도로 주었을 때 좌측에서는 정상적인 반응이 관찰되었으나 우측 흥쇄유 돌근의 근전위가 전혀 관찰되지 않았다(Fig. 2D). 주관적 시 수평 검사에서 우측(시계방향)으로 $3^{\circ}$, 주관적 시수직 검사 에서 우측(시계방향)으로 $5.7^{\circ}$ 편향을 보여 급성 우측전정기 능 저하소견을 보였다.

환아의 의식상태가 명료하고 커니그 징후 및 부르진스키 징 후를 포함한 신경학적 검사에서 정상이었으며 뇌수막염을 의심할 수 있는 증상인 두통을 호소하지 않았고 오심 구토 또한 호전되는 양상을 보여 뇌척수액 검사 및 뇌 자기공명영 상촬영술은 시행하지 않았다. Mumps 바이러스에 대한 항 바이러스 항체검사를 시행하였으며, 검사 결과 $\operatorname{IgM~Ab}$ 가 양 성으로 확인되어 확진을 하였다. 환아는 8 일간의 입원 치료 기간 동안 Solondo(Prednisonone $5 \mathrm{mg}$, 유한메디카, 청주, 대 한민국)를 $1 \mathrm{mg} / \mathrm{kg}$ 의 용량으로 7일간 경구 투여받았으며, 그 후 감량하던 중 퇴원하였다. 우측 청력 소실 및 현훈 발생 8 일째 환아는 자발안진은 소실되었으며 주관적 시수평 검사 에서 우측(시계방향)으로 $2.7^{\circ}$, 주관적 시수직 검사에서 우측

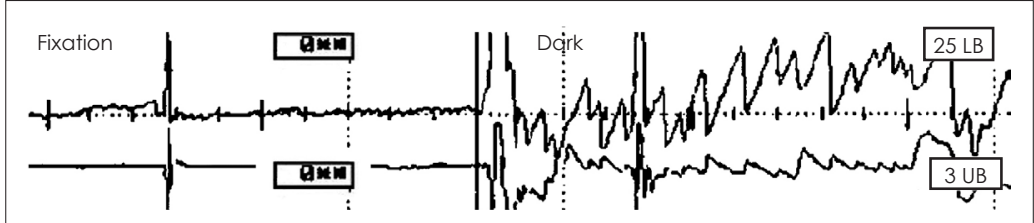

A

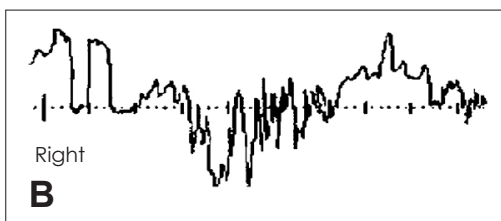

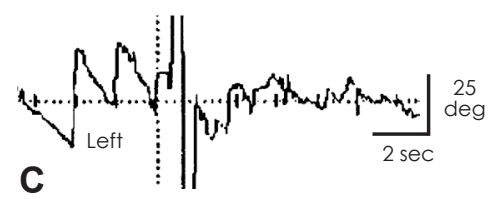

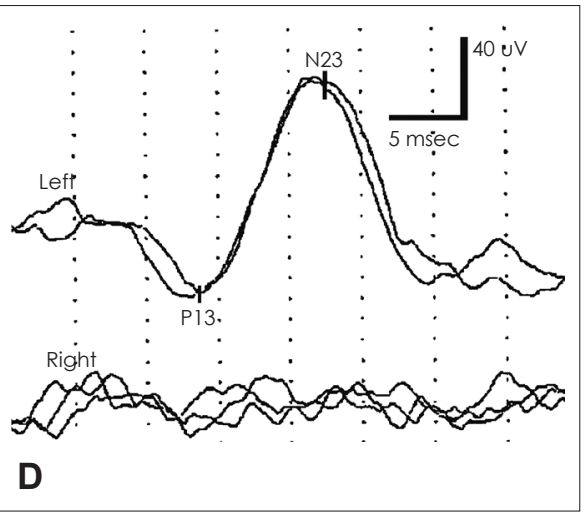

Fig. 2. Vestibular function test. Videonystagmography shows left beating spontaneous nystagmus $(25 \%$ sec) in the dark which is obviously suppressed by visual fixation (A). Right $17^{\circ} \mathrm{C}$ caloric test shows left beating nystagmus $\left(27^{\circ} / \mathrm{sec}\right)$. Considering left beating spontaneous nystagmus, corrected response is $2^{\circ} / \mathrm{sec}(\mathrm{B})$. Left $17^{\circ} \mathrm{C}$ caloric test shows left beating nystagmus $\left(5^{\circ} / \mathrm{sec}\right)$. Considering left beating spontaneous nystagmus, corrected response is $30 \% \mathrm{sec}(\mathrm{C})$. Cervical vestibular-evoked myogenic potential shows normal response in the left side but no responses in the right side (D). 
(시계방향)으로 $1.4^{\circ}$ 로 편향이 감소되었으며, 현훈도 부분적 으로 감소하고 경부 종창도 부분적 호전을 보였으나 청력의 변화는 없었다. 증상 발생 3주째 외래 방문시에 현훈은 추가 적인 호전이 있었으며 비디오안진검사상 자발안진은 없었으 나 여전히 순음청력검사상 우측 전농 소견이었으며 경부 종 창은 완전히 소실되었다.

\section{고 찰}

Mumps 바이러스 감염은 전염성이 있는 바이러스 질환으 로서 감염이 확인된 경우 격리조치가 필요하므로 정확한 진 단이 필요하다. ${ }^{6)}$ 따라서 Mumps 바이러스 감염 진단에 있어 서 이하선의 종창과 같은 특징적인 임상양상을 파악하고 혈 청학적 검사를 통하여 Mumps 바이러스에 대한 항체를 증 명하는 것이 무엇보다 중요하다.

Mumps 바이러스 감염은 약 2 3주의 잠복기를 거치게 되 며 보통 전구증상은 없다고 알려져 있으나 드물게 발열, 두 통, 근육통, 식욕 부진, 구토 등이 나타나기도 한다. ${ }^{6}$ 바이러 스가 체내에 침범하게 되면 구강과 비강 등의 호흡기 세포에 서 일차증식을 한 후 혈행성으로 침샘으로 퍼지게 되며, 약 85\%의 환자에서 주타액선의 종창을 관찰할 수 있다. ${ }^{6}$ 대부 분의 경우 양측 혹은 일측의 이하선을 침범하고 때때로 악하 선을 침범하기도 한다. 혈청학적으로 Mumps 바이러스에 대 한 항체를 검사하여 $\operatorname{IgM}$ 항체가 양성이거나 $\operatorname{IgG}$ 항체가 4배 이상 증가할 때 진단적 가치를 갖는다. ${ }^{7)}$ 본 증례에서는 $\operatorname{IgM}$ 항체가 양성이었기 때문에 Mumps 바이러스 감염으로 진단 할 수 있었다.

Mumps 바이러스 감염에 의한 다양한 합병증이 알려져 있으며 고환염, 부고환염, 뇌수막염, 췌장염, 뇌염 등이 흔한 합병증으로 알려져 있다. 또한 드물지만 Mumps 바이러스 감 염은 심각한 청력 소실을 동반할 수 있다. Mumps 바이러스 감염 후 $0.05 \%$ 에서 청력소실이 발생하였으며 이 중 $45 \%$ 에서
현훈이 동반되는 것으로 알려져 있다.,8) 이는 바이러스가 와 우에 침범하여 내림프액 미로염을 일으키는 기전으로 설명되 고 있다. ${ }^{3)}$ 볼거리 이하선염 이후 청력 소실을 보인 20명의 환 자들에서 동반된 전정기능의 소실에 관한 연구에 따르면, 11 명은 현훈을 호소하지 않았으나 5명에서 온도안진 검사상 전 정기능의 저하가 있었다. 이는 Mumps 바이러스 감염이 전정 계 손상을 일으킬 수 있다는 병인론을 뒷받침한다. ${ }^{8)}$

국내외에서 Mumps 바이러스 감염에 의한 청력 소실 및 전정 기능 저하에 대한 증례가 다수 보고되었으나, ${ }^{3-5,8)}$ 이는 Mumps 바이러스 감염이 이하선 또는 악하선에 선행되고 그 후 청력 소실 및 전정기능 저하가 발생한 경우였다. 저자들의 문헌 고 찰에 따르면 본 증례는 Mumps 바이러스 감염에 대한 보고 중에서 청력 소실 및 전정기능 저하가 선행한 후 이하선염이 발생한 첫 번째 보고로서 Mumps 바이러스 감염에 대한 첫 번째 특이 징후로 이과적 증상이 선행될 수 있음을 보여주 는 증례라고 생각하여 보고하는 바이다.

\section{REFERENCES}

1) Lee JH, Kim YW, Kim JK, Choi DR. Acute unilateral hearing loss associated with Mumps. Korean J Otorhinolaryngol-Head Neck Surg 1995;38(10):1525-9.

2) Kwon HJ, Lee JK, Choi HJ, Ban JH. A case of vestibular neuronitis followed by mumps parotitis in a pediatric patient. Korean $\mathrm{J}$ Otorhinolaryngol-Head Neck Surg 2008;51(4):402-4.

3) Mizushima N, Murakami Y. Deafness following mumps: the possible pathogenesis and incidence of deafness. Auris Nasus Larynx 1986;13 Suppl 1:S55-7.

4) Beal DD, Naunton RF. Mumps hearing loss. A case report. Laryngoscope 1966;76(11):1786-91.

5) Tsubota M, Shojaku H, Ishimaru H, Fujisaka M, Watanabe Y. Mumps virus may damage the vestibular nerve as well as the inner ear. Acta Otolaryngol 2008;128(6):644-7.

6) Hong CW. The Pediatrics. 8th ed. Seoul: Daehan printing \& publishing Co.;2004. p.468-9.

7) Linder TE, Brestel R, Schlegel C. Mumps virus infection: case report of an unusual head and neck manifestation. Am J Otolaryngol 1996;17(6):420-3.

8) Hydén D, Odkvist LM, Kylén P. Vestibular symptoms in mumps deafness. Acta Otolaryngol Suppl 1979;360:182-3. 